\section{Expedition to Borneo}

David Macdonald

Dent, 1982, £9.95

This book is a highly readable account of a three man expedition led by the then recently graduated author in 1972. Subtitled 'The search for proboscis monkeys and other creatures', the reader is warned at the outset that the book is a travelogue with a difference. What results is a collection of interesting natural history facets of the fauna and flora found in Borneo jungles, loosely bound together by the author's and his companions' often naïve and humorous day to day problems of survival and interactions with local people.

The book's strength lies in the gentle way in which Macdonald introduces the reader to the biological principles inherent in ecosystems in general and tropical rain forests in particular.

Although the author in his Foreword gives passing reference to the rapidly dwindling forests of south-east Asia, I personally found an underlying emptiness in the book which might have been improved by occasionally reiterating this theme, especially since some of the book was written with the benefit of hindsight. However, this attractive book gives some of the exotic flavour of Borneo and will appeal to amateur naturalists in particular and all those that aspire to travelling in one of the world's most beautiful places. The high price of the book will limit the number of people who are able to share Macdonald's experiences.

R.E. Stebbings

Monks Wood Experimental Station, Abbots Ripton, Huntingdon, UK.

\section{Plant Extinction; a global crisis Harold Koopowitz and Hilary Kaye Stone Wall Press, 1983, \$16.95}

In an attempt to overcome the anonymity of rare, endangered and extinct plants, as compared with cuddly koalas and pandas, Harold Koopowitz and his journalist co-author Hilary Kaye have succeeded admirably with their case-history approach to plant conservation. They examine five subjects; plants useful to man, extinction in all major life zones, gene banks, the rôle of the amateur and conservation politics. The book is surprisingly accurate not only in species details but also in the names, addresses and activities of the conservation organisations it describes. It is not a balanced review. Instead it describes mostly the obsessions of Harold Koopowitz, director of Irvine Arboretum, University of California, attempting to justify cryogenic seed banks as a viable alternative to the maintenance of genetic resources rather than natural habitats. Consequently, it opposes established conservation organisations, such as the Botanic Gardens conservation co-ordinating body, with their pleas for the maintenance of natural ecosystems. Similarly, when reviewing CITES the authors provide a novel explanation that 'Appendix II' is a threat to species conservation because it affords no protection in native habitats. As much as I disagree with some of the views presented here the layout of the book is excellent. It is provocative and Hilary Kaye's journalism should jolt the most complacent laymen into thinking about the importance of plants. My only real misgivings are with the choice of certain case-studies. For example, despite the tenuous link of heterotrophic nutrition in heathland carnivorous plants with primates, I cannot for the life of me understand why the 'Venus fly-trap' should figure as a case-study example in a chapter entitled 'Feeding the World'! However, the book is well worth reading and I hope at least a few plant conservationists will do so.

C.J. Humphries Department of Botany, British Museum (Natural History)

\section{Birds that Came Back John Gooders} Andre Deutsch, 1983, £12.95

I am often challenged by the public to explain exactly how endangered birds really are. I'll admit that my answers have often been more emotional than informative. I now have the knowledge. The first half of this book gives a splendidly lucid historical account of the depletion of birds in Britain, dealing with prehistoric hunting, medieval cookery, falconry, the invention and development of firearms, and the ironical and vicious circles of dark Victorian days involving 